\title{
Явор МИЛТЕНОВ
}

Институт за български език „Проф. Любомир Андрейчин“, БАН (България, София) yavor.miltenov@gmail.com

\section{Съвпадащи лексикални решения в преписи на Осмокнижието и на Тълковните пророчески книги}

Шестнадесетте старозаветни пророчески книги и Осмокнижието имат, както изглежда, независимо разпространение в славянската средновековна книжнина. Не е известен ранен ръкопис, който да ги е съдържал в едно книжно тяло, отсъстват и аргументи за доказването на такъв изгубен днес протограф. Документирано е със сигурност единствено, че техни текстови версии са се „срещали“ една с друга в по-късни от създаването им компилации, а са били обединявани в цялостни библейски корпуси от XIV в. нататьк. Що се отнася до ранната им текстологическа история от IX-X в., пресечните точки помежду им са две, те засягат библейския текст: първата е свързана с възможността те да съхраняват превод на Първоучителите, а втората - с ясно установения факт на битуването им в Източна България. Редица проучвания са посветени и на опита за доказване на хипотезата, че определени книги възхождат към единния превод, споменат в Житието на св. Методий, и на извличането на езикови характеристики, свидетелстващи за принадлежността им към преславската книжнина. Задачата на изследователите е много усложнена от различни обстоятелства около източниците: наличие на версии с неутрална лексика и на такива с източнобългарски маркери; наличие на версии, които дават възможност за различни интерпретации относно това нов превод ли е извършен или редакция на стар; текстови разклонения, в които е засвидетелствано редактиране, контаминиране или сверка между различни версии, включително с гръцки; отсъствие на пълни критически издания на повечето Книги. Множеството мнения, материали и огромното количество литература вече са били обект на специален преглед и обобщение нееднократно (вж. например [Thomson 1998; Алексеев 1999]), затова бих искал да оставя дискусиите настрана и да фокусирам вниманието си върху друг въпрос. Той се отнася до втората „пресечна точка“, посочена по-горе, и е свързан с езиковата съпоставка между компилирания в Преслав сборник от старозаветни пророчески книги с тълкувания от една страна и т. нар. чети-текст на първите осем книги от старозаветния канон, възхождащ също към източнобългарски протограф. Могат ли езиковите особености да послужат за установяване на степента на общност между тях? И също: Съставянето на сборник с библейски пророчески книги в Преслав единично усилие ли е или е част от по-широка програма за превод или редакция на старозаветните текстове? Целта на настоящата статия е да потьрси посоки, водещи към поне частичен отговор, чрез ексцерпиране на лексика, характерна за Тълковните пророци, от една страна, и за чети-текста на Осмокнижието, от друга. Лексикалните съвпадения биха могли да покажат сходни преводачески или редакторски принципи, въведени 
от един и същ кръг книжовници. От особено значение са редките думи, които са център на настоящата работа.

За щастие, в лексикографските справочници, съставени от А. Х. Востоков и И. И. Срезневски, а също и в речника на Фр. Миклошич, е отразена значителна част от лексиката, която е обект на интерес тук, и то въз основа именно преписи, отразяващи възникналите в Преслав версии. Лексикографските справочници са основният източник за ексцерпцията, сверена, коригирана и допълнена по специални изследвания и издания на библейските книги Битие [Михайлов 1912], Изход [Вилкул 2015], Исус Навин [Вилкул 2017], Исаия [Евсеев 1897], Даниил [Евсеев 1905] и др. В по-малка степен можаха да послужат снабдените с индекс и речник издания на Йезекиил [Тасева, Йовчева 2003] и Малките пророци [Златанова 1998], тъй като в основата им стои дефектен кодекс със значителни липси на текст и голям брой вторични четения (грешки, замени и т. н.).

Това, че текстовете от Осмокнижието и тези от Пророческите книги са имали „преславски“ период в своето съществуване, означава, че в тях е наличен типичен маркиран езиков пласт, но и че трябва да се открива общност, сходства, съвпадения помежду им. Те могат да са от типологическо естество, биха могли също така да са и конкретни. Така например в специално свое изследване Т. Славова [2011] изрежда около петдесет лексеми, за които се предполага произход от езика на прабългарите, и които се срещат в старозаветните и новозаветните текстове. Според публикувания от изследователката списък в преписи на Осмокнижието се откриват например вись $љ \mathbf{k}$

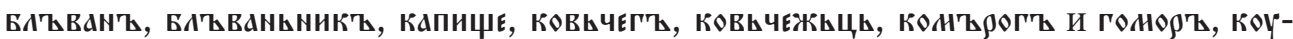
өнгъ, (ко)тиганъ, сокъ 'готвено ястие', тьна 'десет хиляди, безброй', в Тълков-

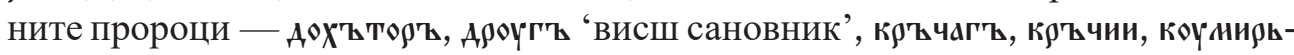

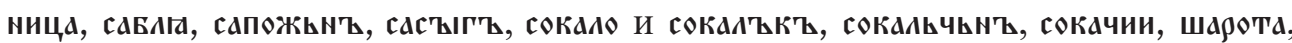
шаръ, ғангъ, а едновременно и в Осмокнижието, и в Тълковните пророци капь, көлиногы, санъчии, съынъ 'кула', за които ще стане дума по-нататък

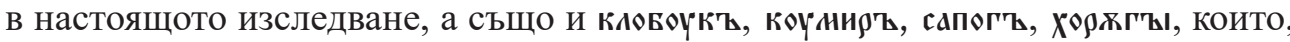
като по-често срещани, остават извън неговия обхват и задачи.

Текстовете от състава на Тълковните пророчески книги и на Осмокнижието съвпадат освен това по отношение на използването на типични синонимни средства, засвидетелствани в небиблейски преводни и оригинални произведения, създадени и преписвани от източнобългарски книжовници. Това е и основната характеристика, въз основа на която се установява „преславският“, както бива наричан, лексикален пласт в тях. Тези синонимни средства са добре известни, тук само изреждам част от тези, които са общи за Тълковните про-

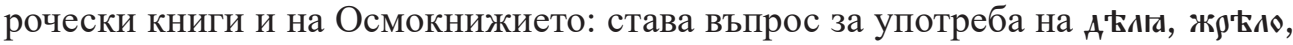

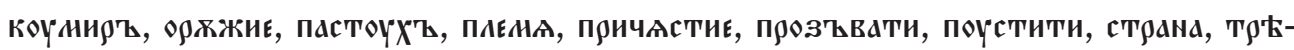

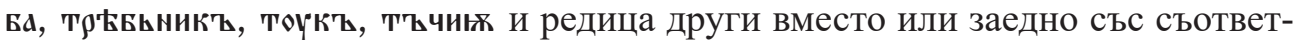
ствия, които биват наричани Кирило-Методиеви, архаични, западнобългар-

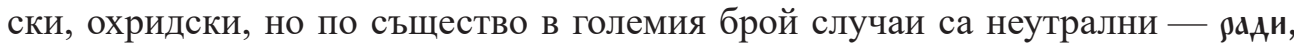

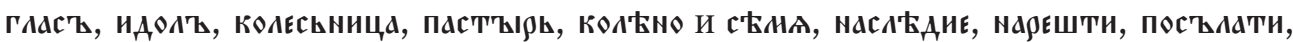




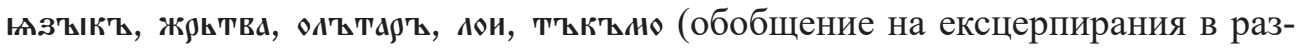
лични изследвания материал вж. напр. у [Славова 2002: 46-52]).

Преписите на чети-текста на книгите от Осмокнижието с източнобългарски особености и версията на Пророческите книги с тълкувания показват общност и по отношение на употребата на лексика с по-широко разпространение. Извън обхвата на проучването остават обичайните словоупотреби, както и тези, които се срещат не много често, но в текстове, създадени в различно време и на различни места и затова не са напълно еднозначни (например в д-

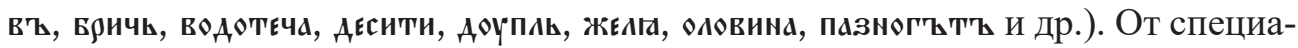
лен интерес тук са по-скоро онези съвпадащи лексеми, които се срещат преди всичко в източнобългарски преводни и оригинални произведения. Ето някои примери:

жєнина 'НаЛОЖница'. Термините жєнина и жєнинда се откриват срещу гр.

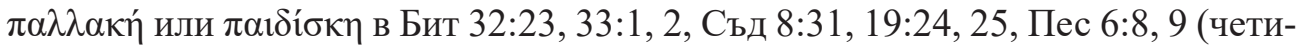
превод), Дан 5:2, 3. Терминът е употребен и в Тълкуванието на Книга на пророк Даниил от Иполит Римски [Илиев 2017: 103, 469], а също и в някои ранни небиблейски преводи като напр. Симеоновия Изборник [Богданова и др. 1993: 56], Пандектите на Антиох, Духовни полета от Йоан Мосх (Синайски патерик), юридически текстове, включително Синтагмата от XIV титула без тълкувания с най-ранен препис в Ефремовската кормчая [Максимович 2010: 84] и др. [Срезн. I: 857, LPSGL: 194, СлРЯ 5: 88, СДРЯ III: 245-246]. Вж. също и жєниничишть 'син на наложница' в Бит 25:6 и в Хрониката на Малала.

здрокъ 'ограничение, определение, заповед, поръчение, задание'. Същест-

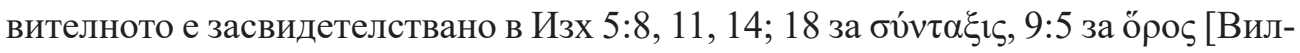

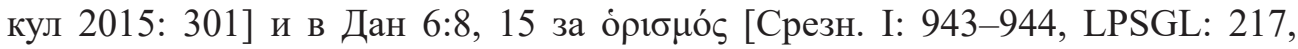
СлРЯ 5: 288, СДРЯ III: 343], вж. също заюьчьнъ ( вестни са ранни употреби в тези значения в Супрасълския сборник (Житие на Конон, л. 30r, срв. [СР 1: 530]), Княжеския изборник [Федер 2008: 99], в сбирките със слова на Григорий Богослов (Слово 11, [Будилович 1875: 344b]) и на Йоан Златоуст (Слово 4 от пълната редакция на Златоструй [Срезн. I: 944]), срв. също Диалозите на Псевдо-Кесарий [Милтенов 2006: 190].

капь 'образ; вместилище; ножница'. В 2Цар 20:8 и Йез 21:3, 4, 5, 30 капь съответства на кодєó ` 'ножница'. В тълкуването на Авак 2:19-20 в гръцкия текст е употребена думата $\theta \varepsilon \varsigma_{\varsigma}$ ‘езическо божество, идол’, но преводачът го е заменил с капь ‘изображение, статуя’ [Златанова 1998: 226]. Лексикографските справочници отбелязват думата в Шестоднева на Йоан Екзарх [Aitzetmüller 1975: 163-164], Супрасълския сборник (включително като референция към Бит 1:26, по капи нашєи и по овљазоү в Златоустовата Хомилия за Лазар, 154v, вж. [SJS 2: 14-15]), словата на Методий Олимпийски, Мъчението на Екатерина, Хомилиара на Миханович, Успенския сборник [Срезн. I: 1195-1196, LPSGL: 283, СлРЯ 7: 69], вж. също хронографската компилация от съчинения на Секст Юлий Африкан и Георги Синкел [Тотоманова 2008: 279, 646-647].

көлинюгъ 'шатра, палатка'. Лексемата е засвидетелствана в Съд 4:11, 7:13, Ис 40:22, за фиксацията в 2Цар 16:22 срв. Тотоманова-Панева 2019: 119, 163. 
Обичайно съответствието ѝ е бкүvи́, така е и в извънбиблейски източници като Германовия сборник [Мирчева 2004: 137], хронографската компилация от съчинения на Секст Юлий Африкан и Георги Синкел [Тотоманова 2008: $282,646]$, Михановичевия хомилиар, преписи на Златоустови творби, Хрониката на Йоан Малала, Мъчението на Арета и тези с него и др. [LPSGL: 298,

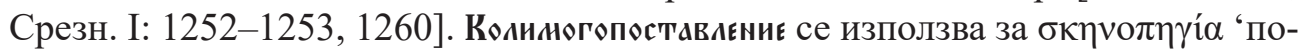
строяване на шатрите (юдейски празник)' в Диалозите на Псевдо-Кесарий [Милтенов 2006: 162-163, 199], а көлиноготворьць и көлиногошьвьць се употребяват в архаични преводи на Златоустови хомилии [Горский, Невоструев 1859: 116, 672].

напьда 'заплата, надница'. Напьда се употребява неколкократно в Петокнижието (Изх 22:15, Втор 23:18, 24: 14, 15) и веднъж в пророческите книги с тълкувания (Мих 1:7). Среща се в сбирки и компилации с източнобългарски произход като напр. Симеоновия Изборник [Богданова и др. 1993: 97], Златоструй (Слова 8 и 80 от кратката редакция [Георгиева 2003: 14d17, 65c30]), Духовни полета от Йоан Мосх (Синайски патерик), Учителното евангелие от Константин Преславски [Срезн. II: 316, LPSGL: 410, СДРЯ V: 178, СлРЯ 10: 170]. Не е ясно дали в този ред трябва да се прибави навьда от превода на Йоан Екзарх на De fide orthodoxа от Йоан Дамаскин [Cрезн. II: 267, LPSGL: 398]. Лексемите от същия корен се срещат предимно в текстове с източнобългарски произход, срв. съществителното напъ 'наемен работник', което според речниците се открива не само в Стария завет (Изх 12:45, 22:15, Лев 22:10, Йов $7: 1,14: 6)$, но и в Пандектите на Антиох, словата на Григорий Богослов, Троицкия сборник, Беседите на Григорий Велики, старинни преводи на жития; напьта в същото значение - в Житието на Нифонт; напьство 'работа като наемен работник’ - отново в словата на Григорий Богослов.

налокъ 'приношение, оброк; клетва; проклятие'. Налокъ се използва и в Осмокнижието, и в Пророческите книги - като съответствие на $\alpha \dot{\alpha} \alpha \varepsilon \mu \alpha$ 'обреченото, оброк, който при неспазване води проклятие’ във Втор 7:26, Съд

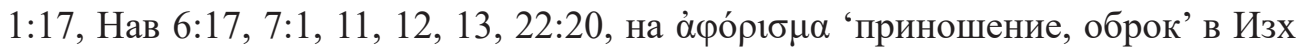

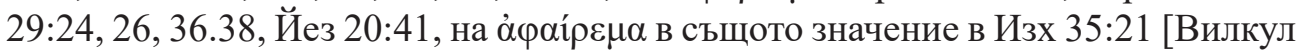
2015: 315], Чис 15:19, Йез 20:31 [Срезн. II: 323, LPSGL: 411, СлРЯ 10: 218219]. В превода на Хомилията за Велики петък от Йоан Златоуст в Супрасълския сборник се използва срещу үп̃чо (л. 217r, срв. [CP 1: 921, SJS 2: 310]), с това или друго съответствие се открива например в сборника с 13 слова на Григорий Богослов (Слово 6 [Будилович 1875: 241d]), Симеоновия Изборник [Богданова и др. 1993: 97], Богословието на Йоан Екзарх [Sadnik 1983: 106], Диалозите на Псевдо-Кесарий [Милтенов 2006: 190], Златоструя (Слово 24 от пълната редакция) и др. По-често се среща в други значения като 'название, наименование' и 'граница, предел'.

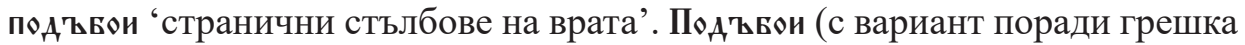

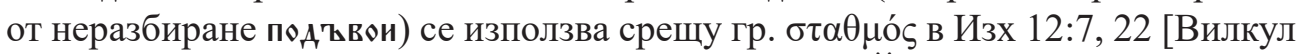
2015: 324], Съд 16:3, Ис 57:8, в библейския текст на Йез 40:48 и в тълкувание-

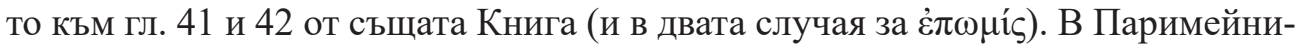
ка се открива в Прит 8:34 и Изх 12:7. Лексикографските наръчници [Срезн. II: 
1051, LPSGL: 597, SJS 3: 104, СлРЯ 15: 223, СДРЯ VI: 545] добавят примери от Пандектите на Антиох, Беседите на Григорий Велики, а у Кирил Туровски и в сборника Мерило праведно употребата е свързана с препратки към библейските текстове. Регистрирана е също в хронографската компилация от съчинения на Секст Юлий Африкан и Георги Синкел, тук отпратката е към Съд 16:3 [Тотоманова 2008: 328, 652], сборника с 13 слова на Григорий Богослов (Слово 11, [Будилович 1875: 341a]), Шестоднева на Йоан Екзарх [Aitzetmüller 1975: 272] и Юдейската война от Йосиф Флавий [Пичхадзе и др. 2004: 240].

постав'ъ 'тъкан, плат, платно'. В преписи на Книга Изход постав'ъ стои срещу гр. хапакс vұбтó (Изх 31:4, срв. [Вилкул 2015: 326]). В Книга на пророк Исаия с тълкувания думата се използва срещу гр. їбо́́ (Ис 30:17, 38:12, 59:5, 6, срв. [Евсеев 1897: 99]). Такова е и съответствието в Пандектите на Антиох,

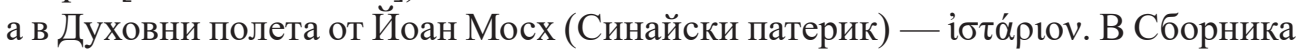
с 13 слова на Григорий Богослов поставъ се среща като еквивалент на й $\alpha \sigma \mu \alpha$ (Слова 5 и 13 [Будилович 1875: 169d, 374b]). Лексемата е засвидетелствана и в Шестоднева на Йоан Екзарх [Aitzetmüller 1975: 282]. Други фиксации не са регистрирани в Срезн. II: 1259-1260 и LPSGL: 638.

раздоль 'долина'. РАздоль и ९дздолив се срещат в преписи на библейските старозаветни книги в превод на различни съответствия - напр. Бит 23:2 (за

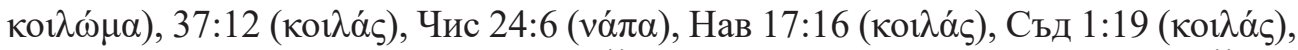

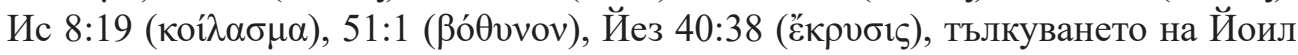

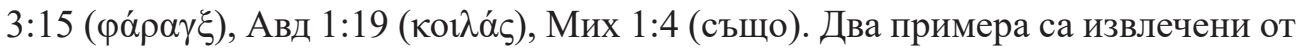
старинни преводни жития, един — от патерик, един от хронографската компилация от съчинения на Африкан и Синкел [Тотоманова 2008: 350] и няколко от късни руски текстове (срв. [Срезн. III: 34-35, 153, LPSGL: 775, СлРЯ 21: 187 $188])$.

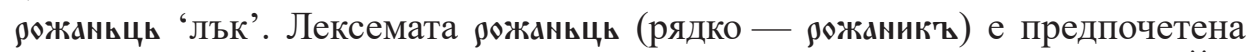
пред лжкү в Бит 27:3, 48:22 (срв. [Михайлов 1912:375]), Нав 24:12, сьщо в Йез 39:3, 9 и тълкуванието на този стих, ПлЙер 2:4, 12, Ис 5:28, 51:2, Ос 1:7, Авак 3:9 (срв. [SJS 3: 647, LPSGL: 802, Срезн. III: 140-142, СлРЯ 22: 195, 198]). Среща се и в Псалтира с тълкувания от Теодорит Кирски [Погорелов 1910б: 182]. Небиблейските съчинения, в които се употребява ९ожаньць, са сборникът с 13 слова на Григорий Богослов (Слово 2 [Будилович 1875: 70с]), Диалозите на Псевдо-Кесарий [Милтенов 2006: 165-166], Чудото на св. Георги с българина [Кодов 1969: 143, Ангелов 1955: 172] и Ипатиевската летопис. В Тълковната палея лексемата е част от старозаветния текст [Славова 2002: 437].

сам'ъчии 'управител (на двореца)'. Фиксации на титула самчии са известни от гръцки и латински извори. Сред домашните източници, в които се среща този прабългаризьм, могат да се посочат руски и южнославянски преписи на

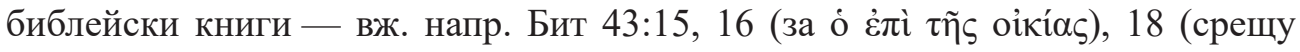

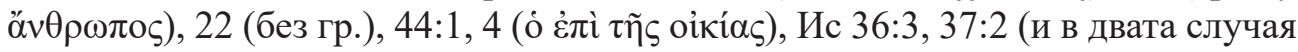
съответствие е oíкovópos). Другите примери са извлечени от Супрасьлски

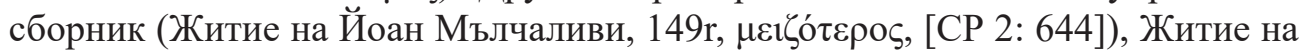

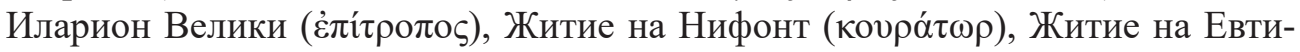


хий по февруарските чети-минеи, Лествица [Срезн. III: 256, LPSGL: 822, Славова 2010: 117-125].

стын' 'кула'. В преписи на старозаветни книги думата е регистрирана напр. в Бит 11:4, 8 [Михайлов 1912: 382], Пес 8:10, Йер 31:38, Йез 26:4, 9, 27:11. Често се използва заедно със синонима стл'ъпъ за превод на $\pi \dot{\rho} \gamma \gamma о \varsigma$,

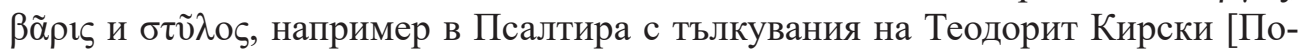
горелов 1910б: 194, 208], Супрасълския сборник [СС: 625, 676], сбирката със слова на Григорий Богослов [Будилович 1875: 82b, 313c, 371a за стл'ыпъ и 223a за съынъ, Слово 5), хронографската компилация от сьчинения на Секст Юлий Африкан и Георги Синкел [Тотоманова 2008: 375, 657-658], Християнска топография (срв. [Срезн. III: 874]; в речника към изданието [Голышенко, Дубровина 1997] е отразена само думата стл'ып'ы, но стынъ фигурира в текста — вж. 23r29), Диалозите на Псевдо-Кесарий [Милтенов 2006: 177-178]. Gъынъ (с вариант соүнъ) се среща и в други паметници с ранна хронология - ЙоанЕкзарховите Шестоднев [Aitzetmüller 1975: 359, 383], Богословие [Срезн. III: 874] и слова [Мирчева 1971: 35б13], Златоструй (напр. Слово 26 от кратката редакция [Георгиева 2003: 54c1]), Духовни полета от Йоан Мосх (Синайски патерик), Тълковната палея и др. (вж. [Срезн. III: 620, 874-875, LPSGL: 903904, 967-968]). Многобройни примери са извлечени от Юдейската война на Йосиф Флавий [Пичхадзе и др. 2004: 395-396].

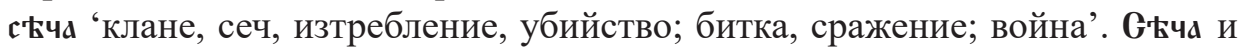
ckчь са засвидетелствани в Чис 21:23, 24 (и в двата случая срещу фóvos), 31:21,

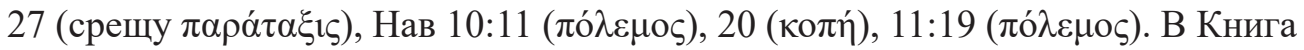
на пророк Исаия непьлната ексцерпция свидетелства за два примера - в Ис

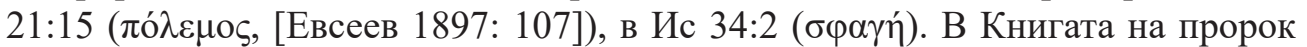
Йезекиил след пълната обработка на дефектното южнославянско копие се наброяват общо 15 примера в библейския текст и тълкуванията [Илиева 2013: 457], а в текста на Малките пророци след сьщата процедура - три, всички в коментара (към Йоил 3:13, 15, Ав 2:12, [Златанова 1998: 534]). Към този материал могат да се прибавят сьщо съчьн'ъ в Чис 21:23-24, с'ъчищє в 1Цар 14:20 [Тотоманова-Панева 2019: 143], скчьць и скчьца в Ис 3:2, 13:5, Йоил 3:9. G'чьь

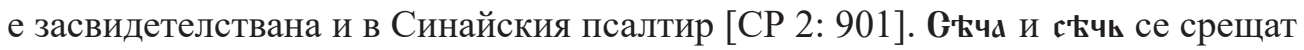
в редица старинни български преводи като Симеоновия Изборник [Богданова и др. 1993: 174], Богословието на Йоан Екзарх [Sadnik 1983: 215], хронографската компилация от съчинения Африкан и Синкел [Тотоманова 2008: 376, 658], Диалозите на Псевдо-Кесарий [Милтенов 2006: 48], Хрониката на Йоан Малала, примери са извлечени също от Юдейската война на Йосиф Флавий [Пичхадзе и др. 2004: 399], Житието на Андрей Юродиви [Молдован 2000: 748] и от ранни руски източници [Срезн. III: 903-904, 905-906, LPSGL: 973, СлРЯ 24: 105-113].

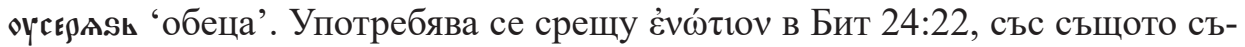
ответствие - и в Изх 32:2, 35:22 [Вилкул 2015: 349], Ис 3:21 [Евсеев 1897:

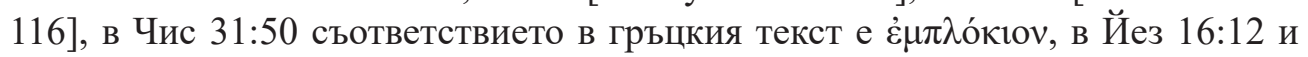
коментара - трохібко [Срезн. III: 1264-1265, LPSGL: 1064]. Примери са регистрирани в Шестоднева на Йоан Екзарх [Aitzetmüller 1975: 420], Симеоно- 
вия изборник [Богданова и др. 1993: 187], сборника с 13 слова на Григорий Богослов (Слово 5 [Будилович 1875: 220b], препратка към Прит 25:12), Житието на Текла и др., включително в късни преводи с преднамерено архаизирана лексика като т.нар. Номоканон при Великия требник [Цибранска-Костова 2011: 474].

Хжћвина 'колиба, къща, дом'. Примерите от библейските книги включват Бит 33:17, 35:15, Изх 1:21, 9:19 [Вилкул 2015: 352], Втор 11:20, Йоил 2:9. Лексемата има фиксации в значителен брой съчинения с източнобългарски произход (част от тях вж. напр. в [Срезн. III: 1374-1375, LPSGL 1092, Милтенов 2006: 182]).

штоүдъ 'великан'. Регистрирана е в преписи на старозаветните книги на следните места: Бит 10:8, 9, 14:5, Чис 13:34, Нав 12:4, 13:12, Ис 3:2, 13:3, 49:24, а прилагателното штоүдыскъ - във Втор 1:28 и Йез 32:11. Штоудъ, штоүдовинъ се използват също в Псалтира с тълкувания на Теодорит Кирски [Погорелов 1910a: 236], сборника с 13 слова на Григорий Богослов (Слово 2 [Будилович 1875: 47a, 81a]), Симеоновия Изборник [Богданова и др. 1993: 196], Паренесиса [Aitzetmüller 1990: 554], Огласителните поучения на Кирил Йерусалимски ([Горский, Невоструев 1859: № 114], 12r), хронографската компилация от съчинения на Секст Юлий Африкан и Георги Синкел [Тотоманова 2008: 402, 660], Пандектите на Антиох, Хрониката на Йоан Малала и др. (срв. [Срезн. III: 1611-1612]).

Лексикалният избор в Пророческите книги с тълкувания и в чети-текста на първите осем старозаветни книги съвпада и по отношение на някои редки думи, срещащи се единствено в съпоставяните текстове или имащи още няколко фиксации според лексикографските наръчници.

вонғлица 'нещо, което излъчва благоухание, ароматно масло, тамян'. Rонга-

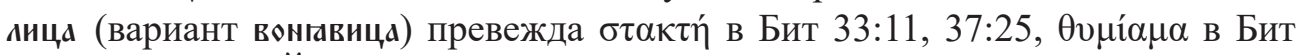

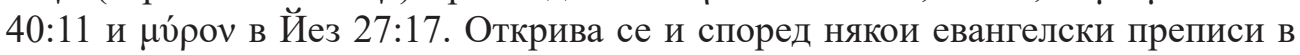

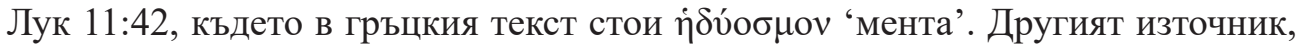
посочен в речниците, е Житието на Теодор Сикейски [Срезн. I: 300, 301, LPSGL: 73] (срв. и воница в сборника Мерило праведно, [СДРЯ I: 474]).

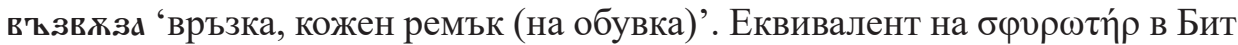
14:23 и Ис 5:27, засвидетелстван и в евангелски преписи двукратно (Мар 1:7, Лук 3:16), където в гръцкия текст е използвана íás. Други примери не са регистрирани в лексикографските справочници (срв. [Срезн. I: 344, LPSGL: 86]), освен този в сборника с 16 слова на Григорий Богослов, където е препратка към Мар 1:7 (СДРЯ II: 25, пюћвжза в [Будилович 1875: 14b]).

здзълити 'причиня зло, оскърбя, обидя'. ЗАзълити е съответствие на како́

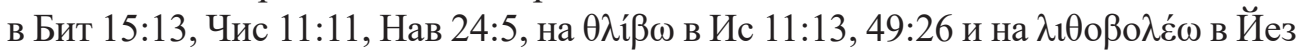

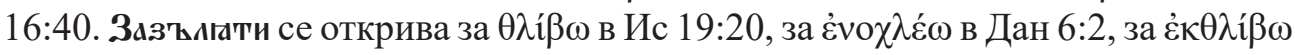
в Мих 7:2 [Срезн. I: 914, LPSGL: 217]. Речниците фиксират употреби на съзъълити в Чис 20:15, 24:24, Рут 1:21, Йер 44:27 и на зАзъљћ'киє в Ис 53:4 [Евсеев 1897: 99], Йона 4:6. Фиксациите в небиблейски източници включват съзълити в Богословието на Йоан Екзарх, здзълғтти в Житието на Елевтерий [СлРЯ 5: 198] и ЗАЗһАєниє в сборника с 16 слова На Григорий Богослов [СДРЯ III: 304]. 
засовъ 'напречна греда, резе'. Засовъ е рядка дума в славянската книжнина

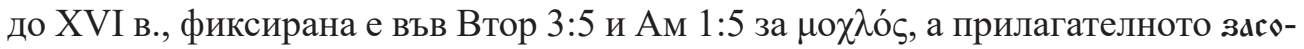
витьв е hapax legomenon в 3Цар 6:32 [Срезн. I: 947, LPSGL: 217, Тотоманова-Панева 2019: 132]. Един от малкото примери, извлечени от старинни текстове, е този от Беседите на Григорий Велики (вж. [SJS 1: 657], за употреби в късни руски съчинения срв. [ СлРЯ 5: 298]).

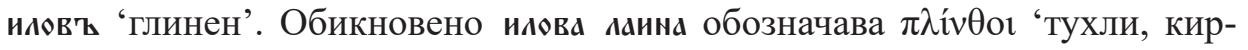
пич', срв. Бит 11:3 (два пъти, но има копия, които пазят заемката плин-øъы) и Ис 24:23. Съществителното ияъ се открива в някои преписи в Изх 31:5 и единственият друг ранен текст, който го пази, е преводът на едно от словата на

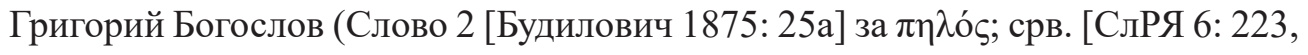
224] за късни примери за иль и ильвъ от руски текстове).

көюүп 'брашно'. В това значение думата е засвидетелствана неколкократно

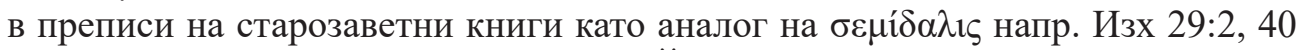
[Вилкул 2015: 308], Лев 2:1, Чис 6:15, Йез 16:13, 19, Ис 1:13, 39:40, 66:3, вж.

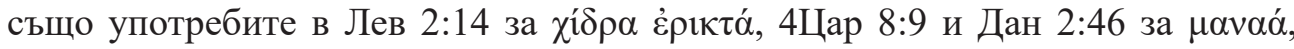
$\mu \alpha ́ v v \alpha$ [Срезн. I: 1335, LPSGL: 314]. Други сигурни примери почти отсъстват (вж. Синтагмата от XIV титула без тълкувания с най-ранен препис в Ефремов-

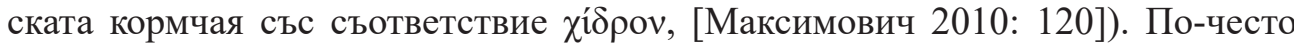
срещана е употребата в множествено число көюүпы 'парчета, късове' - речниците посочват такава напр. в словата на Григорий Богослов, Симеоновия Изборник, словата на Кирил Йерусалимски, Златоструя и др., срв. и көюүпица в най-ранните евангелски преписи.

ланна 'строителен материал, тухли, кирпич’. Както бе отбелязано, обикно-

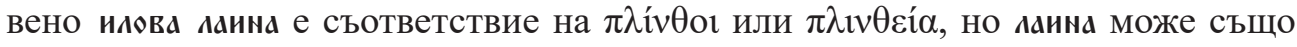
така да се използва и без прилагателното — както е напр. в Бит 11:3, Изх 1:14, $5: 14,16,19$, Ис 9:10, 24:23, Йез 4:1 и в коментарите към 4:1-2 и 4:3, Наум 3:14 [Срезн. II: 5, LPSGL: 331], вж. също употребата на лаиньнъ в Изх 5:7, 8, 11, 18 [Вилкул 2015: 309]. В това значение е регистрирана от речниците само в превода на хомилиите на Григорий Богослов (Слова 2 и 11 [Будилович 1875: 25a, 346d] за $\pi \lambda \imath v \theta \varepsilon i ́ \alpha)$.

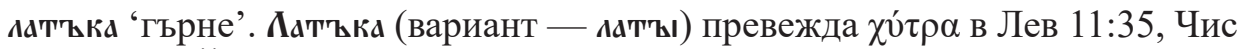

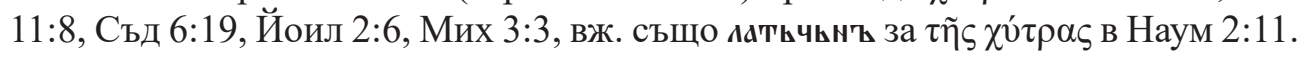
Лексикографските наръчници добавят пример за употреба на съществителното в Житието на Александър от чети-минея за февруари и в други, значително по-късно възникнали източници [Срезн. 2: 12, СДРЯ IV: 392, СлРЯ 8: 180].

өБино 'около, наоколо'. Типичен лексикален маркер, който се среща със значителна честота в старозаветните книги — напр. Изх 16:13, 19:12, 25:10, 11, 24, 25, 26:17, 27:17, 28:32, 33, 28:34 (два пъти), 29:16, 21, 30:3, 36:20, 31, 40:19 (срв. [Вилкул 2015: 317]), Втор 25:19, Нав 21:40, Йез 41:10, Йоил 3:11, 12 и предисловието към Книга на пророк Амос [Срезн. II: 508, LPSGL: 465, СлРЯ 12: 53]. Единственият извънбиблейски текст, в който е фиксирана думата според речниците, е Житието на Партений от Чети-минея за февруари. 
өБржчь 'гривна'. Речниците фиксират употреба на өьлжчь в това рядко значение в Чис 31:50, Йез 16:11 и коментара към този стих, Ис 3:19, гръцкото

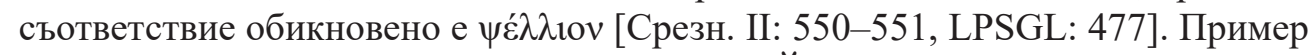
от ранен текст е извлечен от Шестоднева на Йоан Екзарх [Aitzetmüller 1975: 237, вж. също примерите и значенията в СлРЯ 12: 164-165, СДРЯ V: 539].

овоүшиє 'долната месеста част на ухото'. ОБоүшиє (винаги в съчетание с

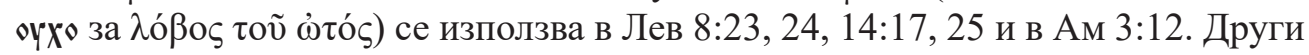
фиксации на думата не са известни.

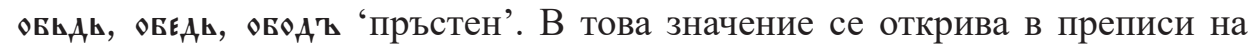
Книга Изход $(25: 11,13,14,26,26: 29,27: 4,7,10,11,30: 4,36: 23)$, Съдии (8:21, 26) и в пророческите книги с тълкувания - Ис 58:5, Йер 52:18, тълкуването на Ам 1:5 (вж. [Срезн. II: 500, LPSGL: 462, 463, Вилкул 2015: 318]). Няколко примера са извлечени от произведение, приписвано Кирил Туровски [СДРЯ V: 471], срв. също [СлРЯ 12: 28]), но всички те изглеждат като препратки към библейския текст. Срв. също оводъ в Княжеския изборник [Федер 2008: 148]. Умалителното өьєдьца 'обеца' е известно от хронографската компилация от съчинения на Секст Юлий Африкан и Георги Синкел [Тотоманова 2008: 309]. ОБьдо в Супрасълския сборник лексикографите са склонни да превеждат като ‘съкровище, наследство’ [CP 2: 45, CC: 400, SJS 2: 498], но може и да е решение на преводача за небуквален превод.

погеєььникъ 'хляб, печен чрез заравяне в жарава, в пепел'. Гръцкото

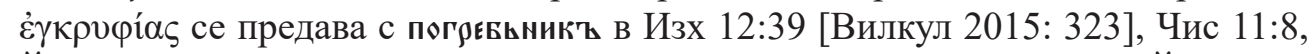
Йез 4:12 [Срезн. II: 1021, LPSGL: 590]. Открива се и в Похвалата за Йоаким и Мария от Козма Веститор според препис в Макариевите чети-минеи [ СлРЯ 15: 201]. Отсъствието на повече фиксации може да се обясни с липсата на гръцкия еквивалент в небиблейски текстове (както свидетелства [Lampe]).

пождь 'Дъно на яма, под; основа, темел; трюм'. Лексемата се използва като превод на є̌ $\delta \alpha \varphi о \varsigma$ в Йер 31:35 и в тълкуването на този стих, Йез 41:20, на коџ $\lambda$ п́

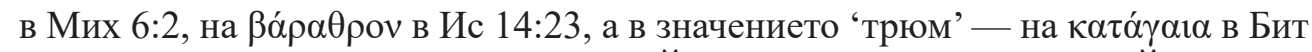
6:16 [Михайлов 1912: 225], на коџ $\lambda$ в Йона 1:5 и в тълкуването на Йона 1:10. Примери от други текстове не са засвидетелствани в лексикографските наръчници (вж. [Срезн. II: 1080, LPSGL: 603-604, СлРЯ 16: 96]).

прахн'кти 'превръщам се в прах'. В старозаветни книги на два пъти се из-

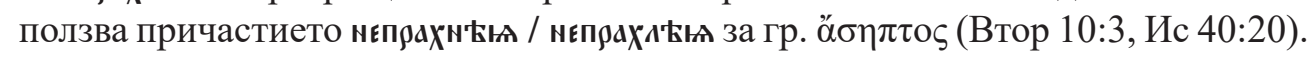
Други примери не са извлечени (според [Срезн. II: 414, LPSGL: 436]), освен еднократната употреба на пюхн'кти в историята за Варлаам и Йоасаф [СДРЯ VII: 478]. Срв. също прилагателното плахн'мъ в Савината книга [CР 2: 352].

притък'ъ 'халка'. Още една лексема, която се използва предимно в старинни преводни текстове. В старозаветните книги стои срещу крі́ко (Изх 26:6, 11, 27:10, 11, 30:6, 37:6, 10, Йов 40: 21), чаגís (Изх 30:4, срв. [Вилкул 2015:

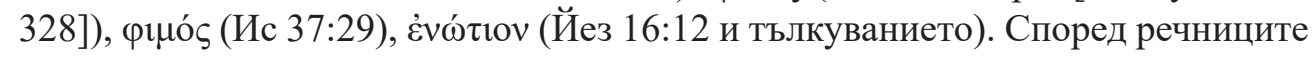
се среща в ограничен кръг текстове [Срезн. II: 1481, LPSGL: 685]. Пример за нейна употреба се открива в Учителното Евангелие, съставено от Константин Преславски - като превод на крі́ко в препратка към Ис 58:5, а в Хомилията 
за Цветница от Йоан Златоуст в Супрасълския сборник (л. 159v, [CР 2: 393]) на крıкíov. Регистрирана е и в Беседата против богомилите от презвитер Козма [Давидов 1976: 235].

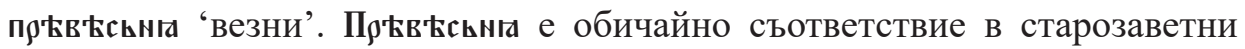

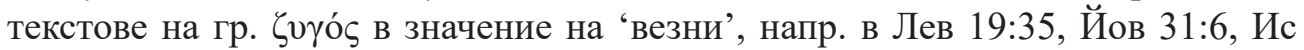
40:15, 46:6, Йер 32:10, в текста и тълкуванието на Йез 5:1, в Йез 45:10, в Ам 8:5. Среща се в Псалтира с тълкувания от Теодорит Кирски, срв. също и

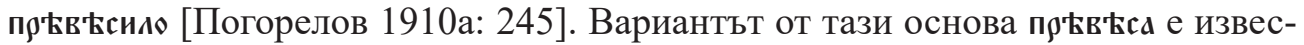
тен от Супрасълския сборник, няколко ранни жития, Диалозите на Псевдо-Кесарий, където обозначава съзвездието Везни [Милтенов 2006: 254] и др. [Срезн. II: 1625, LPSGL: 720, СДРЯ VIII: 50].

пжгы 'топка, топче'. Думата пжгы по й-основи и пжгвица се употребяват срещу гр. рої́ко , което означава 'нар' и оттам — 'топка' и 'топче, копче'. Що се отнася до библейските книги, примери са ексцерпирани от Изх 28:29, 30, 36:33 и Йер 52:23, срв. също пжгвичьнъ в Изх 28:29 [Вилкул 2015: 326]. Останалите източници се изчерпват според речниците с Житието на Теодор Сикейски и Житието на Сава от Дометиан [Срезн. II: 1723, LPSGL: 764, СлРЯ 21: 40]. Пжгвица се среща и в Краткия Златоструй (Слово 64 [Георгиева 2003: 144a33]).

түск'ъ 'приспособление за мачкане на грозде, лин, точило'. Обичайното съответствие на гр. $\lambda$ үó́ в в библейски преписи е точнль. В някои евангелия обаче (Мат 21:33, 35:47, Мар 12:1), като и в преписи на старозаветните книги се предпочита синонима ткскъ - Изх 22:29 [Вилкул 2015: 347], Ис 5:2, 16:10, 63:2, Ос 9:2, Йоил 1:17, 2:24, 3:13. Известен е пример за тази словоупотреба от Житието на Никифор от февруарските чети-минеи [Срезн. III: 1094], както и от сборника със слова на Григорий Богослов (Слово 6 [Будилович 1875: 234c].

жсккица 'гъсеница'. В тази форма, без начално г-, думата се среща в Лев 11:22, в Йоил 1:4 (в библейския текст веднъж и три пъти в тълкуванието), 2:25, в Ам 4:9 и в коментара към 5:5 със съответствие ка́ $\mu \pi \eta$. Речниците посочват също и пример от краткия Златоструй (Слово 40), където се използва в отпратка към Йоил 2:23-25 ([Срезн. III: 1301] под оүстница), но всъщност фиксациите са най-малко две (срв. [Георгиева 2003: 3d32, 128a35-36]).

Разгледаните общи места между Тълковните пророчески книги и чети-текста на Осмокнижието по отношение на лексиката не винаги могат да се класифицират еднакво.

В едни случаи може би дадени словоупотреби са резултат от редакция, както при двойката илюва лынна - плин-љы (гърцизмът би следвало да е първичен). В други случаи изглежда, че няма как да не са били част от първоначалния превод, както е при повечето от посочените редки думи и хапакси (отговарят на една и съща гръцка дума, фиксирани са само или почти само в Стария завет).

Различно е и разпространението на лексемите от този пласт в текстове, създадени до XV в. Едни остават ограничени до старозаветните Книги (напри-

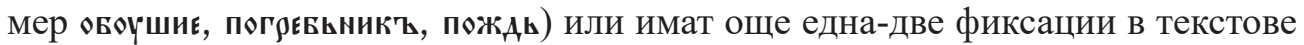
с източнобългарски архетип (например вонғлица, възвжза, здзълити, көоүпа, 


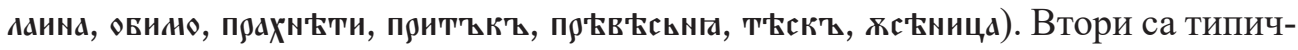
ни за по-голям брой произведения с преславски произход (синонимните вари-

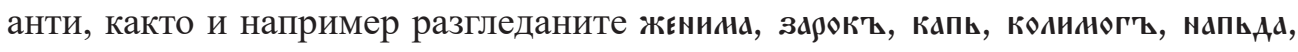

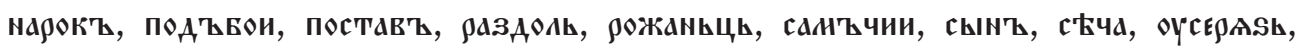
Хльвина, штоүдъ). Трети се появяват не само в ранни текстове, но и в по-късни,

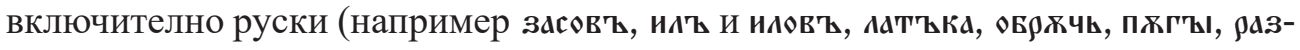

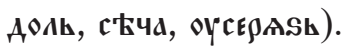

Тези класификации обаче, трябва да признаем, са плод на съвременния опит и методи да се групира и осмисли даден езиков материал. За преписвача, редактора, преводача от края на IX или началото на X в. е важно да предаде своя източник по най-добрия възможен начин посредством употребяваните от него и неговите съвременници езикови средства. Тези езикови средства остават маркери за стила на редактора или преводача и за принципите, които той спазва, независимо от по-късното си отпадане или утвърждаване в книжовната практика. В този смисъл извлечените лексеми, макар и разнородни, се обединяват от стойността им на маркер, на индивидуализиращ белег, диференциращ и групиращ признак. Те свидетелстват не само за сходно време и място на обработка на разгледаните старозаветни книги (което е ясно от използването на прабългаризми и на типични синоними), но съдържат и сведение за стила, заложен в преславските им протографи: особено впечатляващи са съвпаденията с текста на словата на Григорий Богослов - проучването им в съпоставителен план трябва да продължи с мисъл за това, че те може са резултат от труда на един и същи кръг книжовници.

В заключение, възможен отговор на поставените в началото на работата въпроси. Могат ли езиковите особености да послужат за установяване на степента на общност между Тълковните пророчески книги и чети-текста на Осмокнижието? Да, но за по-категорични заключения е необходимо извършването на критически издания и съставянето на гръцко-славянски индекси, които да покажат още по-ясно съвпаденията като брой и значимост. Компилирането на сборник с библейски пророчески книги в Преслав единично усилие ли е или е част от по-широка програма за превод или редакция на старозаветните текстове? Разгледаният материал засилва усещането, че по старозаветните книги може да е работено едновременно - по всичко личи, че ако не цялата, то значителна част от съвпадащия крьг лексика е въведена в текстовете в техния „преславски“ период.

\section{ИСТОЧНИКИ}

Богданова С., Вълчанов В., Досева Ц., Иванов С., Ралева Цв., Христова В., Янева П. Симеонов сборник (по Светославовия препис от 1073 г.). Т. 2. Речник-индекс. София: Издателство на Българската Академия на науките, 1993. 219 с.

Будилович $A$. XIII слов Григория Богослова в древнеславянском переводе по рукописи Императорской Публичной Библиотеки XI века. Санкт-Петербург: Отделение русского языка и словесности Императорской Академии наук, 1875. 285 с.

Вилкул Т. Л. Книга Исход. Древнеславянский полный (четий) текст по спискам XIV-XVI веков. М.: Квадрига, 2015. 368 с. 
Вілкул T. Книга Ісуса Навина. Давньослов'янський четій текст за списками XIV-XVI століть. Упорядкування та вступна стаття Тетяни Вілкул [Київське християнство. Т. 9]. Львів: Видавницво УКУ, 2017. 288 с.

Георгиева Т. Златоструй от ХІІ век. Силистра: РИТТ, 2003. 340 с.

Гольшенко В. С., Дубровина В. Ф. Книга нарицаема Козьма Индикоплов. Издание подготовили В. С. Голышенко, В. Ф. Дубровина. М.: Индрик, 1997. 774 с.

Давидов А. Речник-индекс на презвитер Козма. София: Издателство на Българската Академия на науките, $1976.375 \mathrm{c}$.

Евсеев И. Книга пророка Исайи в древнеславянском переводе. СПб.: Печатня С. П. Яковлева, 1897. $322 \mathrm{c}$.

Евсеев И. Книга пророка Даниила в древнеславянском переводе. Введение и тексты. М.: Тип. Г. Лисснера и Д. Собко, 1905. 183 с.

Златанова Р. Книга на дванадесетте пророци с тълкования. (Старобългарският превод на Стария Завет. Под общата редакция на Св. Николова. Т. І.). София: Акад. издателство „Проф. Марин Дринов“, 1998. 612 с.

Илиев Ив. Ив. Тълкуванието на Книга на пророк Даниил от Иполит Римски в старобългарски превод. София: Институт за литература при БАН, 2017. 425 с.

Максимович К. А. Византийская Синтагма 14 титулов без толкований в древнеболгарском переводе. Славянско-греческий, греческо-славянский и обратный (славянский) словоуказатели. Составил Кирилл А. Максимович. Научный редактор Людвиг Бургманн. Frankfurt am Main: Löwenklau-Gesellschaft e.V., 2010. 584 S.

Молдован А. М. Житие Андрея Юродивого в славянской письменности. М.: Азбуковник, 2000. $759 \mathrm{c}$.

Пичхадзе А. А., Макеева И. И., Баранкова Г. С., Уткин А. А. „История Иудейской войны“ Иосифа Флавия. Древнерусский перевод. Т. 2. М.: Языки славянской культуры, 2004.

Погорелов В. Чудовская Псалтырь XI века, отрывок Толкования Феодорита Киррскаго на Псалтырь в древнеболгарском переводе. СПб.: Отделение русского языка и словесности Императорской Академии наук, 1910а. 276 с.

Погорелов В. Словарь к толкованиям Феодорита Киррскаго на Псалтырь в древне-болгарском переводе. Варшава, 1910б. 245 с.

Тасева Л., Йовчева М. Книга на пророк Иезекиил с тълкования. Подбор на гръцкия текст: Т. Илиева. (Старобългарският превод на Стария Завет. Под общата редакция на Св. Николова. Т. 2.). София: Кирило-Методиевски научен център - БАН, 2003. 454 с.

Федер У. КънАжии изборникъ за възпитание на канартикина. Т. 1. Увод и показалци. Велико Търново: Св. св. Кирил и Методий, 2008. 249 с.

Aitzetmüller R. Das Hexaemeron des Exarchen Johannes. Bd. 7. Graz: Akademische Druck u.- Verlagsanstalt, 1975. $515 \mathrm{~S}$.

\section{СЛОВАРИ}

Срезн. - Срезневский И. И. Материалы для словаря древнерусского языка по письменным памятникам. T. I-III. СПб.: издание Отделения русского языка и словесности Императорской академии наук, 1893-1903.

СДРЯ - Словарь древнерусского языка (XI-XIV вв.). T. I-XII-. М.: Русский язык; Азбуковник, 1988-2019-.

СР - Старобългарски речник / Отг. ред. Д. Иванова-Мирчева. Т. І. София: Издателство „Валентин Траянов“, 1999. 1120 с.; Т. ІІ. София: Издателство „Валентин Траянов“, 2009. 1328 с.

СлРЯ - Словарь русского языка XI-XVII вв. Вып. 1-31-. М.: Наука; Азбуковник; Нестор-История; ЛЕКСРУС, 1975-2019-.

ССС - Старославянский словарь (по рукописям X-XI веков). Под редакцией Р. М. Цейтлин,

Р. Вечерки и Э. Благовой. М.: Русский язык, 1994. 842 с.

Lampe - Lampe G. W. H. A Patristic Greek Lexicon. Oxford: Oxford University Press, 1961. 1568 p.

SJS - Slovník jazyka staroslovìnského - Lexikon linguae palaeoslovenicae / Hlav. red. J. Kurz, Z. Hauptova. T. 1-4. Praha: Nakladatelství Československé Akademie Věd, 1958-1997. 


\section{ЯВОР МИЛТЕНОВ}

\section{ЛИТЕРАТУРА}

Алексеев А. А. Текстология славянской Библии. Санкт-Петербург: Дмитрий Буланин, 1999. 254 с. Димитрова М. Песен на Песните в средновековни славянски кирилски ръкописи: преводни съответствия на грьцкия текст в Септуагинта. // Онгъл. Електронно списание. 2019. Год. ХI. Бр. 16. С. 302-353 [http://www.spisanie.ongal.net/broil6/8_mdimitrova.pdf] (последно посещение 05.05.2020).

Милтенов Я. Диалозите на Псевдо-Кесарий в славянската ръкописна традиция. София: Авалон, 2006. $590 \mathrm{c}$.

Михайлов A. B. Опыт изучения текста книги Бытия пророка Моисея в древнеславянском переводе. Варшава: тип. Варшав. учеб. окр., 1912. 460 с.

Славова T. Владетел и администрация в ранносредновековна България. Филологически аспекти. София: ПАМ, 2010. 342 c.

Славова T. Прабългаризми в старобългарския превод на Библията // Следите на словото. Юбилеен сборник в чест на 60-год. на проф. дфн Д. Иванова. Пловдив, 2011. С. 64-74.

Тотоманова А.-М. Славянската версия на Хрониката на Георги Синкел. София: Университетско издателство „Св. Климент Охридски“, 2008. 684 с.

Тотоманова-Панева М. Книги Царства в славянската хронографска традиция (Кирило-Методиевски студии. Кн. 27). София: Кирило-Методиевски научен център - БАН, 2019. 212 с.

Цибранска-Костова М. Покайната книжнина на Българското средновековие IX-XVIII век. София: Издателство „Валентин Траянов“”, 2011. 556 с.

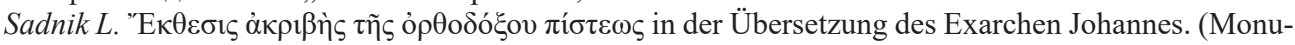
mentae linguae slavicae, 5). Bd. 4. Freiburg: U. W. Weiher, 1983. 279 S.

Thomson F. J. The Slavonic Translation of the Old Testament // Interpretation of the Bible. Ljubliana : Sloven. akad. znanosti in umetnosti ; Sheffield : Sheffield acad. press, 1998. P. 605-920. 